\title{
Fruit physical characteristics, proximate, mineral and starch characterization of FHIA 19 and FHIA 20 plantain and FHIA 03 cooking banana hybrids
}

\author{
George Amponsah Annor ${ }^{*}$, Prudence Asamoah-Bonti and Esther Sakyi-Dawson
}

${ }^{*}$ Correspondence:

georgeannor@gmail.com

Department of Nutrition

and Food Science, University

of Ghana, P O Box LG 134,

Legon-Accra, Ghana

\begin{abstract}
Cooking banana and plantain (Musa spp. AAB and ABB groups), have over the years been affected by pest and diseases, resulting in various organizations developing disease resistant hybrids with superior agronomic potential. The characteristics of these improved varieties needs to be studied to ascertain their suitability for use in various food systems. This study aimed at evaluating the physical characteristics, proximate and minerals composition, and characterizing the starch of plantain and a cooking banana hybrid release by Fundación Hondureña de Investigación Agrícola (FHIA), and comparing them to a local landrace in Ghana. FHIA 19 and FHIA 20 plantain, Apentu pa (a local landrace) and FHIA 03 cooking banana hybrid were used for the study. Their physical characteristics, proximate and mineral composition were determined at the proximal, midsection and distal hand positions. Starch granules and cells were then examined under light microscope. Ranges obtained for protein content for FHIA 20, FHIA 03 and FHIA 19 were 3.01-3.40, 2.66-2.91 and 2.81-2.91\%. Potassium was found to be the most abundant mineral in all the cultivars. The highest mean value of 982.5-1013.76 mg/100 $\mathrm{g}$ was obtained for FHIA 19. There were significant differences $(p<0.05)$ in the proximate and mineral composition of the varieties, however no significant difference exited between the hand positions. The largest starch granule size was found in FHIA 19 hybrid. FHIA 03 was also composed predominantly of two types: longitudinal and rounded granules with each type grouped together. The new plantain hybrids compared very well with the local landrace hence making them suitable to be incorporated into local food systems.
\end{abstract}

Keywords: Plantain, Cooking banana, Proximate, Starch

\section{Background}

Plantain and cooking banana (Musa spp. AAB and ABB groups) is cultivated mainly as a carbohydrate staple in many developing countries, especially in Africa (IITA 2012). According to the Food and Agriculture Organization of the United Nations statistical division (FAOSTAT 2013), 106,714,205 tonnes and 37,877,805 tonnes of banana and plantains was produced worldwide, with about $16 \%$ banana and $72 \%$ plantain respectively produced in Africa. Banana, cooking banana and plantain exports are essential

(c) 2016 The Author(s). This article is distributed under the terms of the Creative Commons Attribution 4.0 International License (http://creativecommons.org/licenses/by/4.0/), which permits unrestricted use, distribution, and reproduction in any medium, provided you give appropriate credit to the original author(s) and the source, provide a link to the Creative Commons license, and indicate if changes were made. 
for the economies of Central and South America and the West Indies (Sakyi-Dawson et al. 2008). Production levels of plantains and cooking banana are however affected by several factors. Notable amongst these factors are diseases such as the black sigatoka (Mycosphaerella fijiensis), a serious leafspot disease (Stover and Simmonds 1978). To reduce this significant effects of diseases on the production levels of plantain and cooking bananas, institutions such as the International Institute of Tropical Agriculture (IITA) Nigeria and Fundación Hundureña de Investigación Agricola (FHIA), Honduras have developed several cultivars of plantain and banana which are disease and pest resistant, high yielding and with good postharvest qualities that are being tested and or distributed to farmers in plantain growing areas. The need to characterize these new and improved varieties to assess their suitability in various food systems, and their eventual adoption in various diets is very important. This study aimed at evaluating the fruit quality characteristics, proximate and mineral composition and starch characteristics of new and promising plantain and cooking banana introduced into Ghana by FHIA in Honduras and compared to Apantu pa plantain; a local cultivar.

\section{Results and discussions}

\section{Physical characteristics}

The physical characteristics of the plantain and cooking banana cultivars are summarized in Tables 1 and 2. The bunch weights were notably heavier than that observed for tetraploid plantain hybrids TMPx 1658-4 and TMPx 548-9 and triploid cooking banana landrace Fougamou respectively (Ferris et al. 1996). The cooking banana hybrid FHIA

Table 1 Physical characteristics of plantain and cooking banana cultivars

\begin{tabular}{llllc}
\hline Characteristics & Cultivars & Mean & Minimum & Maximum \\
\hline Bunch weight $(\mathrm{kg})$ & FHIA03 & $25.3 \pm 2.0$ & 22.0 & 28.0 \\
& FHIA20 & $22.6 \pm 1.4$ & 20.0 & 25.0 \\
& FHIA19 & $22.7 \pm 2.4$ & 20.0 & 26.0 \\
No of hands on a bunch & Apantu pa & $7.8 \pm 2.6$ & 7.2 & 9.8 \\
& FHIA03 & $9.0 \pm 0.2$ & 8.0 & 10.0 \\
& FHIA20 & $8.9 \pm 0.9$ & 8.0 & 10.0 \\
& FHIA19 & $8.9 \pm 0.9$ & 8.0 & 6.0 \\
\hline
\end{tabular}

Mean values ( $\mathrm{g} / 100 \mathrm{~g}$, dry matter basis) from triplicate analysis \pm standard deviation

Table 2 Fruit characteristics of plantain and cooking banana cultivars

\begin{tabular}{llllll}
\hline Characteristics & Hand position & \multicolumn{2}{l}{ Cultivars } & & \\
\cline { 3 - 5 } & & FHIA 03 & FHIA 20 & FHIA 19 & Apantu pa \\
\hline Fruit width (cm) & Proximal & $16.0 \pm 0.2$ & $13.2 \pm 0.6$ & $14.0 \pm 0.4$ & $16.0 \pm 0.4$ \\
& Midsection & $15.3 \pm 0.0$ & $13.1 \pm 0.0$ & $13.0 \pm 0.0$ & $15.3 \pm 0.0$ \\
& Distal & $13.3 \pm 0.2$ & $11.3 \pm 0.2$ & $11.5 \pm 0.1$ & $14.4 \pm 0.3$ \\
Fruit length (cm) & Proximal & $17.5 \pm 0.1$ & $22.5 \pm 0.2$ & $23.0 \pm 0.2$ & $26.5 \pm 0.4$ \\
& Midsection & $16.5 \pm 0.2$ & $21.0 \pm 0.6$ & $21.5 \pm 0.1$ & $25.0 \pm 0.2$ \\
& Distal & $15.5 \pm 0.1$ & $17.5 \pm 0.1$ & $17.5 \pm 0.0$ & $17.5 \pm 0.0$
\end{tabular}

Mean values (g/100 g, dry matter basis) from triplicate analysis \pm standard deviation 
03 was the heaviest, though the shortest amongst the three varieties studied. A weight of $25.3 \mathrm{~kg}$ was recorded for the FHIA 03 compared to 22.7 and $22.6 \mathrm{~kg}$ of the FHIA 19 and FHIA 20 respectively. Compared to the Agbagba plantain landrace which has an average of 15 fingers per bunch (Ferris et al. 1996), the FHIA 19 and FHIA 20 plantain hybrids had fewer fingers per bunch. Fruits of the cooking banana hybrid FHIA 03 were shorter and bigger compared to the plantains hybrids. In many West African markets, the shorter finger length FHIA 03 cooking banana would be associated with sweet dessert bananas. This is likely to reduce its market value as a cooking cultivar. The number of hands on a bunch was similar for the three varieties. The pulp of the FHIA 19 plantain hybrid was firmer than that of the FHIA 20 which was in turn firmer than the pulp of the FHIA cooking banana hybrid (Table 3). The pulp of bananas having higher contents of pectin has been shown to be softer than plantains (Dadzie 1993). The firmness of the plantain hybrids is obviously an advantage in post harvest management. Loss of firmness during ripening leads to higher incidence of mechanical damage, making the ripened hybrids more difficult to manage. The results also indicated that the samples from the distal hand positions of the two plantain and cooking banana hybrids has firmer pulps as compared to samples from the proximal and midsection hand positions.

The colour of plantains and cooking bananas probably contributes more to the assessment of quality by the consumer than any other single factor. In some West African countries, if the pulp colour of plantain and cooking bananas is white, consumers relate that to immaturity, howerver, if the pulp is orange/yellow it indicates that the fruit is mature (Dadize 1998). The FHIA 03 cooking banana pulp was lighter in colour than the two plantain hybrids (Table 4), which were more yellow. The yellow colour may be due the carotenoids in the plantain.

The Apantu pa Landrace plantain had a higher percentage pulp per finger than the plantain and cooking banana hybrids, with a range of 1.7-1.2. FHIA 20 and FHIA 19 had $0.9-1.1$ and 1.2-1.3 respectively with FHIA 03 cooking banana having a significantly lower $(\mathrm{p}<0.05)$ pulp to peel ratio of $0.8-0.9$ (Table 3$)$. There was also a significant reduction in \% pulp from the proximal to the distal sections of the bunches of all the cultivars.

Table 3 Pulp firmness, pulp colour and starch content of plantain and cooking banana hybrids

\begin{tabular}{lllll}
\hline Cultivar & Hand position & Pulp to peel ratio & Pulp firmness (g/s) & Starch content (\%) \\
\hline FHIA 03 & Proximal & 0.93 & 2171.0 & $74.9 \pm 0.0$ \\
& Midsection & 0.91 & 2156.7 & $74.7 \pm 0.0$ \\
\multirow{3}{*}{ FHIA 20 } & Distal & 2152.6 & $74.4 \pm 0.1$ \\
& Proximal & 1.14 & 4163.1 & $79.9 \pm 0.2$ \\
& Midsection & 1.10 & 4158.6 & $79.3 \pm 0.0$ \\
FHIA 19 & Distal & 0.90 & 4148.6 & $79.1 \pm 0.0$ \\
& Proximal & 1.27 & 4756.7 & $81.5 \pm 0.0$ \\
& Midsection & 1.24 & 4730.7 & $81.6 \pm 0.0$ \\
& Distal & 1.20 & 4751.4 & $80.3 \pm 0.1$ \\
& Proximal & 1.68 & 5742.9 & $85.0 \pm 0.1$ \\
& Midsection & 1.45 & 5720.6 & $84.3 \pm 0.2$ \\
& Distal & 1.21 & 5715.1 & $85.0 \pm 0.0$
\end{tabular}

Mean values ( $\mathrm{g} / 100 \mathrm{~g}$, dry matter basis) from triplicate analysis \pm standard deviation 
Table 4 Pulp colour of plantain and cooking banana hybrids

\begin{tabular}{llrl}
\hline Cultivar & \multicolumn{1}{l}{ L } & \multicolumn{1}{l}{$\mathbf{a}^{*}$} & $\mathbf{b}^{*}$ \\
\hline FHIA 03 & $84.5 \pm 0.1$ & $1.9 \pm 0.1$ & $64.4 \pm 0.1$ \\
FHIA 20 & $56.5 \pm 0.2$ & $15.0 \pm 0.0$ & $68.1 \pm 0.2$ \\
FHIA 19 & $56.2 \pm 0.2$ & $14.0 \pm 0.1$ & $68.0 \pm 0.1$ \\
Apantu pa & $53.1 \pm 0.5$ & $16.9 \pm 0.1$ & $80.4 \pm 0.3$
\end{tabular}

Mean values ( $\mathrm{g} / 100 \mathrm{~g}$, dry matter basis) from triplicate analysis \pm standard deviation

\section{Proximate composition}

The results of the proximate composition are summarized in Table 5. The moisture content was determined on the fresh plantain and cooking banana samples. It is clear from the table of results that the two plantain hybrids FHIA 19 and FHIA 20 have higher moisture contents than the cooking banana FHIA 03. Comparing the three new varieties to the Apentu pa, the results showed that the Apentu pa had the lowest moisture content. The moisture contents of the varieties studied were significantly different, however with respect to the hand positions, the differences in moisture contents were not significantly different. The moisture contents of the samples which is inversely related to its dry matter have been shown to be a useful quality-screening attribute. Sensory evaluation of both boiled and fried musa fruit showed that the higher the dry matter contents, the better the eating quality. Selection of new progeny based on dry matter content provides an efficient way of eliminating materials with low quality fruit (Ferris et al. 1996). It has also been reported that dry matter decreases with maturation (Trease and Evans 1989). This increase is due to carbohydrate utilization during maturation and osmotic transfer of water from the peel to the pulp. The osmotic transfer occurs due to the marked difference in osmotic pressure between peel and pulp during maturation (Loeseck 1950). The fat contents of the plantain and cooking banana samples were generally low. Crude fat contents of the FHIA 19, FHIA 20 plantain hybrids and the cooking banana hybrid FHIA 03 were $0.08,0.12$ and $0.16 \%$ respectively. These values are lower than that reported by earlier (Giami and Alu 1993). The difference in the crude fat content of the plantain

Table 5 Proximate composition of Plantain and cooking banana cultivars

\begin{tabular}{lllllll}
\hline Cultivar & Hand position & Moisture (\%) & Protein (\%) & Ash (\%) & Fibre (\%) & Fat (\%) \\
\hline FHIA 03 & Proximal & $74.3 \pm 0.2$ & $2.7 \pm 0.1$ & $2.8 \pm 0.1$ & $4.3 \pm 0.0$ & 0.0 \\
& Mid section & $73.5 \pm 0.1$ & $2.9 \pm 0.1$ & $2.9 \pm 0.1$ & $5.6 \pm 0.0$ & $0.3 \pm 0.0$ \\
& Distal & $75.0 \pm 0.4$ & $2.8 \pm 0.4$ & $3.1 \pm 0.2$ & $4.2 \pm 0.0$ & $0.2 \pm 0.0$ \\
FHIA 20 & Proximal & $66.7 \pm 0.1$ & $3.0 \pm 0.1$ & $2.6 \pm 0.1$ & $5.4 \pm 0.0$ & $0.2 \pm 0.0$ \\
& Mid section & $66.7 \pm 0.1$ & $3.4 \pm 0.6$ & $2.9 \pm 0.3$ & $6.0 \pm 0.1$ & $0.0 \pm 0.0$ \\
& Distal & $67.0 \pm 0.1$ & $3.1 \pm 0.1$ & $2.9 \pm 0.2$ & $6.7 \pm 0.2$ & $0.2 \pm 0.0$ \\
FHIA 19 & Proximal & $65.2 \pm 0.4$ & $2.8 \pm 0.1$ & $2.9 \pm 0.2$ & $5.5 \pm 0.0$ & 0.0 \\
& Mid section & $65.0 \pm 0.6$ & $2.9 \pm 0.1$ & $2.5 \pm 0.3$ & $6.2 \pm 0.0$ & $0.2 \pm 0.1$ \\
& Distal & $65.6 \pm 0.1$ & $2.8 \pm 0.1$ & $3.0 \pm 0.3$ & $5.9 \pm 0.0$ & $0.1 \pm 0.0$ \\
Apantu pa & Proximal & $54.3 \pm 0.2$ & $2.5 \pm 0.1$ & $2.0 \pm 0.2$ & $4.0 \pm 0.0$ & $0.2 \pm 0.0$ \\
& Mid section & $55.0 \pm 0.2$ & $2.8 \pm 0.1$ & $2.0 \pm 0.3$ & $4.2 \pm 0.0$ & $0.2 \pm 0.0$ \\
& Distal & $53.1 \pm 0.5$ & $2.9 \pm 0.1$ & $2.0 \pm 0.2$ & $3.9 \pm 0.1$ & $0.2 \pm 0.0$
\end{tabular}


and cooking banana hybrids may be due to the differences in varieties and geographical factors (Emaga et al. 2007). Even though the fat contents were generally low, differences between the varieties were significantly different.

The fibre concentrations of all the samples studied were below $7 \%$. The cooking banana hybrid FHIA 03 was found to have the lowest fibre content.

The crude protein concentrations of the plantain varieties were higher than the cooking banana. The FHIA 20 plantain hybrids recorded the highest protein content. Crude protein of plantain is lower than other starchy staples. About $5.6 \mathrm{~g} / 100 \mathrm{~g}$ has been reported for sweet potatoes (Bradbury and Halloway 1988), 6.4-9.6 g/100 g for yams (Agbor-Egbe and Treche 1995) and about $1.7 \mathrm{~g} / 100 \mathrm{~g}$ reported for cassava (Gomez and Valdivieso 1983). One hundred grams of the plantains and cooking banana hybrid can supply only $6 \%$ of the RDA for protein.

More than $74 \%$ of the plantain and cooking bananas was composed of starch. The starch content of the plantains was higher that the cooking banana (Table 3). Differences in the starch contents of various plantain and cooking banana cultivars have been reported. Plantain hybrids TMPx 1658-4 and TMPx-148-9 and TMPx 612-74 have been reported to have starch contents of 74,72 , and $70 \%$ (dry weight) and plantain landrace Agbagba and ObinoL'Ewai have starch content of 75 and 73 \% (dry weight)Cooking bananas Pelipita Fougamou and Cardaba have 73, 69, and 74\% (dry weight) respectively (Ferris et al. 1996).

The Apantu pa landrace plantain had the highest amylose (32.65 \%) content will therefore produce a more viscose paste and is likely to retrograde faster when cooked. FHIA 19 and FHIA 20 recorded 28.1 and $26.1 \%$ amylose respectively. FHIA 03 had the lowest quantity of amylose $(25.1 \%)$. This different amylose contents will affect the quality of certain processed forms of plantains like the traditional $f u f u$ which is made by pounding boiled plantains.

\section{Mineral composition}

Considerable variations in mineral concentration in plants have been generally observed. Though little is known regarding the environmental and physiological processes that regulate the uptake of minerals in plants, the influence of species, and concentration of minerals in the soil and age of plant have been reported. Plantains and cooking bananas have been observed to accumulate potassium. The high levels of potassium and low levels of sodium obtained in this study will make these cultivars useful in low sodium diets. Potassium was found to be the most abundant mineral in all the cultivars (Table 6). The highest mean value $(\mathrm{mg} / 100 \mathrm{~g}$ dry weight) of $982.5-1013.8$ was obtained for FHIA 19. FHIA 03 had 994-1001; FHIA 20 had 726.4-817.1 whilst Apantu pa had the lowest value of 769.0-773.2. Mean values ( $\mathrm{mg} / 100 \mathrm{~g}$ dry weight) obtained for sodium were rather low for all the cultivars. Values obtained for FHIA 03, FHIA 20, FHIA 19, and Apantu pa were 2.0-2.4, 1.2-3.1, 1.6-3.1, and 2.0-2.1 respectively. The mean values of phosphorus which was also quite high indicates that $100 \mathrm{~g}$ of the plantain and cooking banana hybrids can supply about one quarter of the RDA for phosphorus which is $800 \mathrm{mg}$, whilst Apantu pa landrace plantain can supply $19 \%$. The appreciable amounts of calcium and magnesium but low levels of iinc and iron obtained in the samples indicate that $100 \mathrm{~g}$ of the plantains and cooking banana hybrids can supply about 4.5 and 
Table 6 Mineral composition of plantain and cooking banana cultivars

\begin{tabular}{lllllllll}
\hline Cultivar & $\begin{array}{l}\text { Hand posi- } \\
\text { tion }\end{array}$ & $\mathbf{N a}$ & $\mathbf{K}$ & $\mathbf{C a}$ & $\mathbf{M g}$ & $\mathbf{F e}$ & $\mathbf{Z n}$ & $\mathbf{P}_{\mathbf{2}} \mathbf{O}_{\mathbf{5}}$ \\
\hline FHIA 03 & Proximal & $2.1 \pm 0.3$ & $994.0 \pm 4.2$ & $12.6 \pm 0.4$ & $33.1 \pm 1.2$ & $2.7 \pm 0.1$ & $0.3 \pm 0.0$ & $220.0 \pm 2.4$ \\
& Mid section & $2.0 \pm 0.3$ & $997.0 \pm 5.3$ & $13.4 \pm 0.5$ & $35.0 \pm 2.1$ & $3.1 \pm 0.0$ & $0.2 \pm 0.0$ & $213.0 \pm 2.2$ \\
& Distal & $2.1 \pm 0.3$ & $1001.0 \pm 5.1$ & $13.4 \pm 0.3$ & $34.3 \pm 0.6$ & $2.2 \pm 0.1$ & $0.3 \pm 0.0$ & $211.0 \pm 3.2$ \\
FHIA 20 & Proximal & $3.0 \pm 0.2$ & $817.1 \pm 4.3$ & $22.6 \pm 0.3$ & $72.8 \pm 3.3$ & $1.1 \pm 0.0$ & $0.3 \pm 0.0$ & $259.2 \pm 2.1$ \\
& Mid section & $1.2 \pm 0.1$ & $726.4 \pm 5.3$ & $26.3 \pm 0.5$ & $70.2 \pm 3.5$ & $4.5 \pm 0.0$ & $0.3 \pm 0.0$ & $267.9 \pm 4.3$ \\
& Distal & $3.1 \pm 0.4$ & $813.2 \pm 5.5$ & $41.2 \pm 0.2$ & $84.9 \pm 5.2$ & $2.2 \pm 0.1$ & $0.4 \pm 0.0$ & $219.8 \pm 1.5$ \\
FHIA 19 & Proximal & $1.6 \pm 0.0$ & $982.5 \pm 4.6$ & $33.1 \pm 0.1$ & $61.5 \pm 3.4$ & $2.6 \pm 0.0$ & $0.3 \pm 0.0$ & $218.4 \pm 2.2$ \\
& Mid section & $3.0 \pm 0.1$ & $1013.0 \pm 5.3$ & $40.4 \pm 0.4$ & $72.1 \pm 5.6$ & $4.1 \pm 0.1$ & $0.3 \pm 0.0$ & $237.2 \pm 2.4$ \\
& Distal & $3.1 \pm 0.1$ & $1013.8 \pm 5.6$ & $42.3 \pm 0.2$ & $74.9 \pm 4.3$ & $3.6 \pm 0.0$ & $0.3 \pm 0.0$ & $259.6 \pm 3.2$ \\
Apantu pa & Proximal & $2.1 \pm 0.1$ & $772.0 \pm 4.4$ & $13.4 \pm 0.1$ & $84.2 \pm 4.4$ & $1.1 \pm 0.0$ & $0.3 \pm 0.0$ & $159.1 \pm 2.2$ \\
& Mid section & $2.1 \pm 0.1$ & $769.3 \pm 6.7$ & $14.3 \pm 0.1$ & $85.9 \pm 2.6$ & $1.1 \pm 0.0$ & $0.3 \pm 0.0$ & $162.0 \pm 2.4$ \\
& Distal & $3.0 \pm 0.1$ & $773.2 \pm 4.4$ & $18.2 \pm 0.2$ & $84.2 \pm 5.4$ & $1.15 \pm .07$ & $0.28 \pm .02$ & $157.01 \pm 2.2$
\end{tabular}

Mean values ( $\mathrm{mg} / 100 \mathrm{~g}$, dry matter basis) from triplicate analysis \pm standard deviation

$1.5 \%$ RDA of calcium respectively, while Apantu pa can supply $2 \%$. One hundred grams of the plantains and cooking banana hybrids can supply about $23 \%$ of the RDA for magnesium, $2 \%$ of the RDA for zinc, and $22 \%$ of the RDA foriron. It is important to note that the iron present in plantain is completely utilized by the human body when ingested (Loeseck 1950).

\section{Starch granules and cell examination}

The largest starch granule size was found in Apantu pa plantain, followed by FHIA 19 and then FHIA 20. The FHIA 03 cooking banana had the smallest granule sizes (Figs. 1, 2). There was also a gradual decrease in starch granule size from the proximal sections to

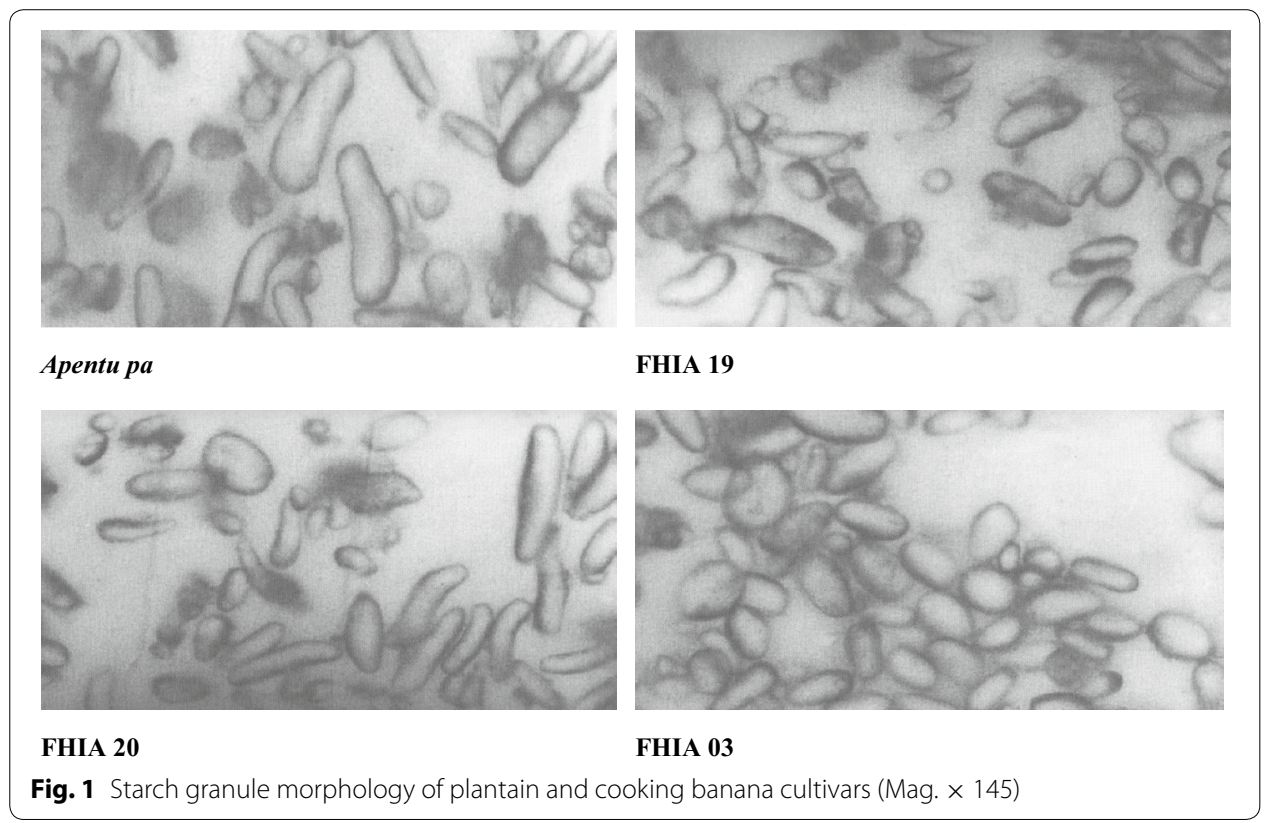




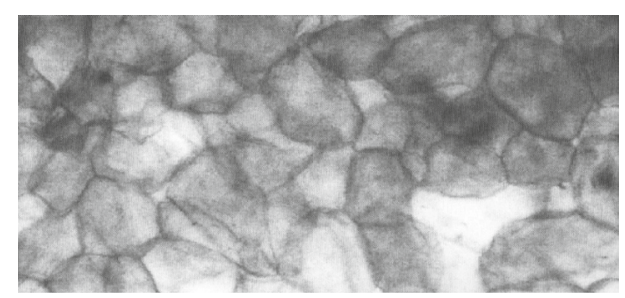

Apentu pa

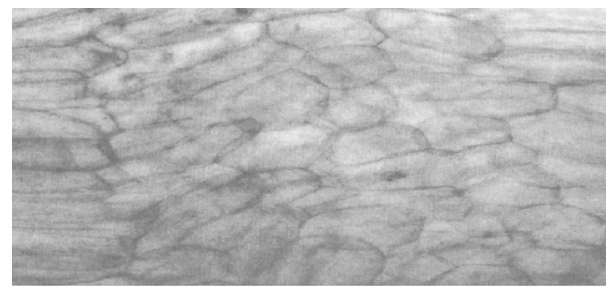

FHIA 20

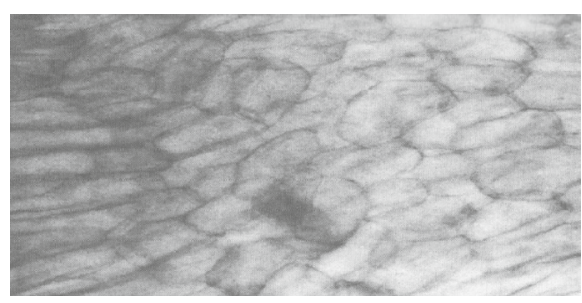

FHIA 19

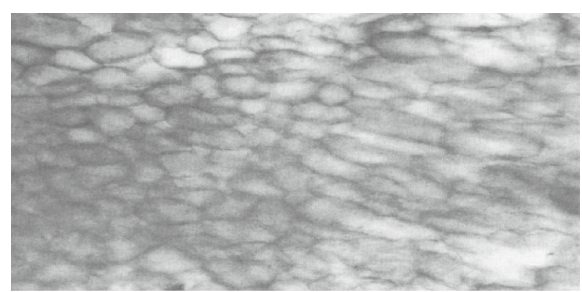

FHIA 03

Fig. 2 Starch cell morphology of plantain and cooking banana cultivars (Mag. $\times$ 145)

the distal sections of all the cultivars. Whereas the Apantu pa consisted predominantly of one type of granules, which were mostly plate like in nature with a few being irregular shaped ones, FHIA 19 and FHIA 20 plantain hybrids consisted of two types of granules: longitudinal and plate-like which were arranged concurrently. FHIA 03 was also composed predominantly of two types of granules: longitudinal and rounded cells with each type of granules grouped together. The starch granule sizes of the cultivars were assessed to find out if there were possible differences among the cultivars. The largest starch granule size was found in Apantu pa plantain. The observed differences in the starch granule sizes of the cultivars may be due to their genetic background. The starch granule size and shape of the hybrids, which were crosses between exotic bananas and plantains varied considerably from that of the landrace. The amylose content has been found to be was relative to the granular morphology (Delpeuch et al. 1978). Small granules have the lowest amylose content whiles the large ones have the highest.

\section{Conclusions}

The new and improved hybrids were heavier and had more hands on a bunch compared to the local Apentu pa landrace. The Apentu pa had more starch and a firmer pulp compared to the new hybrids. All new plantain hybrids compared very well to Apentu pa in terms of the pulp to peel ratio. The FHIA 20 plantain hybrid had the most protein and fibre content amongst the four varieties studied. In terms of the mineral composition, the new varieties significantly had more iron and potassium than Apentu pa. Considerable variation existed in the starch microstructure of the various cultivars. The shape of Apantu pa starch granules consisted predominantly of one type-plate-like to round. The hybrids consisted of two types of granules. Variations in the starch granule size also existed between and within the cultivars. Apantu pa had the largest granule size followed by FHIA 19, FHIA 20 and then FHIA 03. Granule size also decreased from the proximal sections to the distal sections. 


\section{Materials and methods}

\section{Sample selection and preparation}

Fruit quality characteristics of two tetraploid plantain hybrids FHIA 19 and FHIA 20, a tetraploid cooking banana hybrid FHIA 03 and a triploid local landrace plantain Apantu pa were obtained from Volta River Estates Ltd (V.R.E.L.) experimental farms, Akuse, Ghana and used for the study. The tetraploid plantain hybrids of the genomic group $(\mathrm{AAAB})$ and cooking banana hybrid of the genomic group (AABB) were developed through years of breeding and selection by the Fundación Hundureña de Investigación Agricola (FHIA), Honduras. These hybrids have been introduced in Ghana through the Crops Research Institute (CSIR) for testing. The tetraploid plantain hybrids were derived from crosses between triploid plantain landraces (AAB) and exotic diploid bananas (AA). Characteristics of the hybrid genotypes include high yielding, resistance to black sigatoka disease, draught tolerance and are less prone to lodging than plantains. To compare these new varieties to locally available plantain landraces, Apantu $p a$ a false horn triploid (AAB) Ghanaian Landrace plantain was used. This was chosen because it is one of the most preferred plantain types grown and traded in Ghana. The Apantu pa landrace plantains attract highest market prices due to their desirable bunch characteristics and multipurpose nature. It is however susceptible to Black sigatoka disease.

Five bunches of unblemished fruits from each cultivar were selected at random and harvested. The maturity of fruits chosen for this study was 'full three-quarters', meaning that the individual fingers had less prominent angles i.e. fully mature but green: this criterion for maturity is based on the Jamaican practice (Simmonds 1966). The harvesting of bunches was done three times depending on the availability of fruits that reached the required stage of maturity. This means that each variety had 15 bunches for analysis. The harvested bunches were stored at ambient conditions $\left(28-31{ }^{\circ} \mathrm{C}, 56-62 \% \mathrm{RH}\right)$ on a wooden platform. Twenty fruits at the proximal, midsection and distal hand position from the five bunches were randomly selected, washed and peeled. The peeled fruits were cut into slices of $0.5 \mathrm{~cm}$ thick disc using a vegetable slicer (Qualheim-electro-cut, model 101, Qualheim Inc. USA). The slices were then diced, thoroughly mixed thoroughly with a Hobart cutter (model 84142, The Hobart manufacturing Co Ltd, Don Mills Ont. Canada). The sample was freeze-dried using an Edward's bench freeze-drier (Edwards Instrument Ltd., Hornchurch, Essex, UK). Prior to analysis the freeze-dried samples were ground with a Hammer Mill (Christy and Morris Ltd., England) equipped with a $250 \mu \mathrm{m}$ sieve. The flour samples obtained were packaged into polypropylene bags and kept under cold storage $\left(4^{\circ} \mathrm{C}\right)$.

\section{Methods}

\section{Physical characteristics}

Bunch weight The average weight of the bunch was determined on the whole bunch using a Salter and Scale $( \pm 0.1 \mathrm{~g})$.

Fruit length Measurements were done on the outermost curvatures of the fruit. An Inextensible measuring tape was used. The fruit length was measured at the proximal, midsection and distal hand positions of the plantain and cooking banana samples. 
Fruit width Measurements were done at the widest midpoint of the fruit. An Inextensible measuring tape was used. The fruit width was measured at the proximal, midsection and distal hand positions of the plantain and cooking banana samples.

Number of fingers per bunch The number of hands of fruits on each bunch was counted to ascertain the number of hand on a bunch.

Pulp firmness Fruit samples were washed and $1 \mathrm{~cm}$ of fruit pulp was cut transversely at the mid-point perpendicular to the longitudinal axis. The $1 \mathrm{~cm}$ pulp disc was peeled and the peak force (g) required to cut completely through the disc/slice was determined. This was done by using a Warner-Blatzler blade connected to a TA-XT2 texture analyzer, (Stable Micro Systems, Halsmere, and Surrey, England) interfaced with an IBM Computer. The $1 \mathrm{~cm}$ pulp disc was placed flat surface down onto the horizontal mounting place. The pulp firmness was measured at the proximal, midsection and distal hand positions of the plantain and cooking banana samples using a pre-test speed of $10.0 \mathrm{~mm} / \mathrm{s}$, a test speed of $5.0 \mathrm{~mm} / \mathrm{s}$, a post-test speed of $10.0 \mathrm{~mm} / \mathrm{s}$, a distance of $20.0 \mathrm{~mm}$, a force threshold of $20.0 \mathrm{~g}$ and a contact force of $5.0 \mathrm{~g}$.

Pulp colour Colour was measured with a Minolta Colour Meter Model CR-300 (Minolta Camera Co. Ltd. Inc., Tokyo, Japan) using a white porcelain plate with $\mathrm{L}=98.0$, $\mathrm{a}=-0.20$, and $\mathrm{b}=1.65$ as reference. Results were expressed in Hunter $\mathrm{L} \mathrm{a}^{*}$ and $\mathrm{b}^{*}$ values. Three random readings per sample were obtained and averaged. The measuring head was placed on the pulp surface and readings taken in triplicates.

Pulp to peel ratio This was done on weight basis. Pulp and peel weights were determined using a Mettler Toledo AG240 electronic balance $( \pm 0.1 \mathrm{mg})$. The pulp-to-peel ratio was calculated from the pulp and peel weights using the formula:

Pulp to peel ratio $=\mathrm{PW} / \mathrm{FW}-\mathrm{PW}$

where FW = fruit weight, $\mathrm{PW}=$ pulp weight.

Proximate composition The moisture, crude protein $(\mathrm{N} \times 5.7)$, fibre and ash contents were determined by Association of Official Analytical Chemists Approved methods 925.10, 920.87, 920.86 and 923.03 respectively (AOAC 1990).

Starch content Starch content was determined using the modified ferricyanide (acid hydrolysis) method (Bainbridge et al. 1996).

\section{Mineral analysis \\ Wet digestion of sample}

The first step involved in the elimination of the inorganic materials through the procedure of wet ashing. About $0.5 \mathrm{~g}$ of the sample was weighed into a $250 \mathrm{ml}$ beaker. Twentyfive $\mathrm{ml}(25 \mathrm{ml})$ of concentrated nitric acid was added and beaker covered with a watch glass. The sample was digested with great care on a hot plate in a fume chamber until the solution was pale yellow. The solution was cooled and $1 \mathrm{ml}$ perchloric acid (70\% $\left.\mathrm{HClO}_{4}\right)$ added. The digestion was continued until the solution was colourless or nearly 
so (the evaluation of dense white fumes indicates the removal of nitric acid). When the digestion was completed, the solution was cooled slightly and $30 \mathrm{ml}$ of distilled water added. The mixture was brought to boil for about $10 \mathrm{~min}$ and filtered hot into a $100 \mathrm{ml}$ volumetric flask using a Whatman No. 4 filter paper. The solution was then made to the mark with distilled water.

\section{Determination of $\mathrm{Ca}, \mathrm{Mg}, \mathrm{Zn}$ and $\mathrm{Fe}$}

One $\mathrm{ml}$ of the digest was used to determine the $\mathrm{Ca}, \mathrm{Mg}, \mathrm{Zn}$ and $\mathrm{Fe}$ of the sample using the Perking Elmer Precisely A Analyst 400 Atomic Absorption Spectrophotometer with an acetylene flame. The AAS was fitted with $\mathrm{Zn}$ and Fe EDL lamps and $\mathrm{Mg}$ and $\mathrm{Ca}$ CHCL lamps set at wavelengths of $213.86 \lambda, 248.33 \lambda, 285.21 \lambda$ and $422.67 \lambda$ respectively.

\section{Determination of $\mathrm{Na}$ and $\mathrm{K}$}

Two (2) $\mathrm{ml}$ of the digest was used in the determination of sodium and Potassium using the flame photometric method. The photometer (Jenway, United Kingdom) model PF P7 with methane gas was used.

\section{Phosphorus determination}

Two (2) $\mathrm{ml}$ aliquot of the digest was reacted with $5.0 \mathrm{ml}$ molybdic acid (The molybdic acid was prepared by dissolving $25 \mathrm{ml}$ of ammonium molybdate in $300 \mathrm{ml}$ distilled water; with $75 \mathrm{ml}$ of concentrated sulphuric acid in $125 \mathrm{ml}$ of water to get $0.5 \mathrm{l}$ of molybdic acid) $1 \mathrm{ml}$ each of $1 \%$ hydroquinone and $20 \%$ sodium sulphite was added in that sequence, and the solution was made up to $100 \mathrm{ml}$ and allowed to stand for $30 \mathrm{~min}$ in order to allow the colour to stabilize after which the absorption was measured at $680 \mathrm{~nm}$. A standard curve colorimetric reading versus concentration of phosphorus using portions of standard phosphorus solutions (1,2 and $3 \mathrm{ml}$ ) subjected to reactions with molybdic acid, hydroquinone and sodium sulphate solutions was drawn. All readings were corrected by the reading of a blank to eliminate the effect of any colour produced by the reagents.

\section{Starch granules and cell examination Identification of starch granules}

Dried, ground samples were used for the examination of the starch granules. A minute quality of the sample was added to a small drop of water on a slide and thoroughly mixed taking care not to break any air bubbles. The mixture is then covered with cover slip. Excess water was removed by means of a filter paper and a little dilute iodine was run under the cover slip. Microscopical examination was done using a TMS-F Light Microscope and photomicrographs of the slide taken using a Nikon camera (Nikon Co., Tokyo, Japan) attached to the microscope at a magnification of 145 .

\section{Examination of starch cells}

\section{Sample preparation}

Fruit pulp kept under kept under ambient conditions $\left(28-31{ }^{\circ} \mathrm{C}\right)$ were examined. The samples were washed peeled and pulp of dimension $7.5 \mathrm{~mm} \times 5 \mathrm{~mm} \times 5 \mathrm{~mm}$ were 
sectioned using a dissection blade. The slides were cut along the transverse section and the tissues were then examined for their starch microstructure.

\section{Fixation and dehydration}

Ten milliliters of formalin ( $4 \%$ of $40 \%$ commercial formalin) was taken and $0 / 9 \mathrm{~g}$ of pure sodium chloride (Analar grade) added. Distilled water $(100 \mathrm{ml})$ was added and the resulting solution stirred for the dissolution of the sodium chloride. The resulting solution (formol-saline) was adjusted to $\mathrm{pH} 7.6$ with dilute $\mathrm{NaOH}$ and/or hydrochloric acid and used as the fixative. The cut tissues were placed in the fixative for $24 \mathrm{~h}$, washed with distilled water and dehydrated through a graded series of aqueous alcohol (50,70, $90 \%$ and absolute alcohol) each for $30 \mathrm{~min}$. The dehydrated tissues were or de-alcoholized in an antemedia (toluene) for $2 \mathrm{~h}$ (Mahoney 1973).

\section{Embedding}

The cleared samples were impregnated with molten paraffin wax-benzene (50/50) mixture for $1 \mathrm{~h}$. Samples were transferred to molten paraffin wax of melting point $58{ }^{\circ} \mathrm{C}$ for about $1 \mathrm{~h}$ and finally embedded in molten paraffin wax in a mould. The mould was transferred into cold water to solidify the wax (Peacock 1962).

\section{Sectioning}

Sections of tissues $(8 \mu)$ were cut using the laboratory scale sledge microtome (Erma Inc. Tokyo, Japan). Egg albumen solution was spread on the samples slides and the sections floated on it. The slide was warmed on a hot plate sufficiently to soften but not melt the paraffin and any fold in the section flattened out. The water was drained off and the slide left on the hot plate to dry.

\section{Staining and examination}

The fixed tissues on the slides were immersed in Xylene to remove the wax. The dewaxed samples were passed through a series of ethanol (absolute ethanol, 90 and $70 \%$ ). After this treatment, the samples were stained in safranin for $10 \mathrm{~min}$, washed again in a series of ethanol (50, $70 \%$ and absolute) and counterstained in Fast green for 1 min. The samples were then cleared in clove oil and mounted in Euparol (Flatters and Garvett Ltd., England). Examination of starch cells were done using a TMS-F light Microscope and photomicrographs of the slide taken using a Nikon camera (Nikon Co., Tokyo, Japan) attached to the microscope at a magnification of 145 .

\section{Statistical analysis}

Data from the above analysis were subjected to statistical analysis using Statgraphics (Statgraphics Plus 3.0 for Windows, Rockville, USA). Descriptive statistics was done to describe the data. ANOVA was used to determine whether significant differences $(\mathrm{p}<0.05)$ exist between the different varieties. 


\section{Acknowledgements}

The authors have duly acknowledged all who contributed to the study.

\section{Competing interests}

The authors declare that they have no competing interests.

Received: 2 December 2015 Accepted: 29 May 2016

Published online: 21 June 2016

\section{References}

Agbor-Egbe T, Treche S (1995) Evaluations of the chemical composition of Camerounian yam germplasm. J Food Compos Anal 8:274-283

AOAC (1990) Official methods of the association of official analytical chemists. AOAC, Arlington

Bainbridge Z, Tomilins K, Wesby A (1996) In: Ratham C (ed) Methods for assessing quality characteristics of non-grain starch staples. (Part 3; Lab methods). Natural Resources Institute, Chatham, Kent, UK

Bradbury JH, Halloway WD (1988) Chemistry of tropical root crops: significance for nutrition and agriculture in the Pacific. Australian Centre for International Agricultural Research, ACIAR Monograph No. 6. Canberra, pp 68-76

Dadize BK (1998) Post-harvest characteristics of black Sigotoka resistant banana, cooking banana and plantain hybrids Technical guidelines IMIBAP 4

Dadzie BK (1993) Report on a visit to Ghana and Nigeria to identify the important post-harvest selection criteria of West African cooking bananas and plantains. 17 February 24 March 1993. Project No. C0361. Natural Resources Institute report

Delpeuch F, Favier JC, Charbonniere R (1978) Characteristics of starch of tropical plant foods. Ann Technol Agric 27:809-826

Emaga TH, Andrianaivo RH, Wathelet B, Tchango JT, Paquot M (2007) Effects of the stage of maturation and varieties on the chemical composition of banana and plantain peels. Food Chem 103(2):590-600

Faostat F (2013) Agriculture organization of the United Nations (2011). FAO. Retrieved am from http://faostat3.fao.Org/ faostat-gateway/go/to/download/Q/QC/S. Acceso, 20

Ferris RSB, Adeniji T, Chukwu U, Akalumhe YO, Vuylsteke D, Ortiz R (1996) Postharvest quality of plantains and cooking bananas. In: Ortiz R, Akoroda MO (eds) Plantain and banana: production and research in West and Central Africa. Nigeria: IITA Ibadan, pp 15-22

Giami SY, Alu DA (1993) Changes in composition and certain functional properties of ripening plantain. Food Chem 50:134-140

Gomez G, Valdivieso M (1983) The effect of variety and plant age on cyanide content, chemical composition and quality of cassava roots. Nutr Rep Int 27:857-865

International Institute of Tropical Agriculture (IITA) (2012) Banana and plantain. Research to Nourish Africa, Ner Loeseck WH (1950) Bananas, vol 1, 2nd edn. Interscience Publication, New York

Mahoney R (1973) Laboratory Techniques in Zoology. 2nd edn. Rutherworth and Co.Publishers Ltd. London, pp 215-238

Peacock HA (1962) Elementary Microtechniques. 3rd edn. Edward Arnold Publishers Ltd. London, pp 59-154

Sakyi-Dawson E, Asamoah-Bonti P, Annor GA (2008) Biochemical changes in new plantain and cooking banana hybrids at various stages of ripening. J Sci Food Agric 88(15):2724-2729

Simmonds NW (1966) Bananas. Longman, London

Stover RH, Simmonds NW (1978) Classification of banana cultivars. In: Stover RH, Simmonds NW (eds) Bananas, 3rd edn. Wiley, New York, pp 97-103

Trease GE, Evans WCA (1989) Textbook of pharmacognosy, 13th edn. Bailliere, Tindall, London, pp 180-181

\section{Submit your manuscript to a SpringerOpen ${ }^{\circ}$ journal and benefit from:}

- Convenient online submission

Rigorous peer review

- Immediate publication on acceptance

Open access: articles freely available online

- High visibility within the field

Retaining the copyright to your article

Submit your next manuscript at $\boldsymbol{\nabla}$ springeropen.com 